\title{
Мощный одномодовый непрерывный узкополосный линейно поляризованный полностью волоконный Үb лазер с порогом модовой нестабильности более 100 ВТ
}

\author{
А.А. Сурин ${ }^{1, *}$, А.А. Мольков ${ }^{1,2}$, Т.Е. Борисенко ${ }^{1}$, К.Ю. Прусаков ${ }^{1,2}$ \\ ${ }^{1}$ НТО «ИРЭ-Полюс» \\ ${ }^{2}$ Московский физико-технический институт (Государственный Университет) \\ *E-mail: asurin@ntoire-polus.ru
}

DOI:10.31868/RFL2018.47-48

Благодаря рекордным мощностям оптического излучения, надежности и высокому качеству пучка волоконные $\mathrm{Yb}$ лазеры являются незаменимым инструментом в области индустрии и науки [1]. На сегодняшний день выходная мощность волоконных одномодовых лазеров превосходит единицы киловатт в непрерывном режиме и сотни киловатт в импульсном режиме. Существует огромное множество вариантов реализации таких лазеров: различные оптические схемы, поляризованные и неполяризованные варианты, длина волны излучения варьируется в диапазоне от 0.98 до 1.15 мкм. Однако спектральная ширина линии подобных лазеров в полностью волоконном исполнении довольно большая (> 1 нм). До сих пор генерация относительно небольших оптических мощностей (сотни ватт) с малой спектральной шириной линии менее 0.1 нм непосредственно в маломодовом активном $\mathrm{Yb}$ волокне затруднена из-за эффекта модовой нестабильности (МН) [2].

Согласно работе [2], порог $\mathrm{MH}$ в $\mathrm{Yb}$ усилителе находится на уровне примерно 5 Вт в случае узкополосного (0.1 нм) сигнала на входе. В работе [3] был предложен подход с гибридной накачкой на двух длинах волн, позволяющий поднять порог модовой нестабильности. В данной работе получено до 2 кВТ мощности на длине волны 1080 нм, но спектральная ширина линии в данном случае -4.9 нм. Нам удалось поднять порог модовой нестабильности в лазере со спектральной шириной линии 0.15 нм на уровень более 100 Ватт за счет использования альтернативной оптической схемы, представленной на рисунке 1.

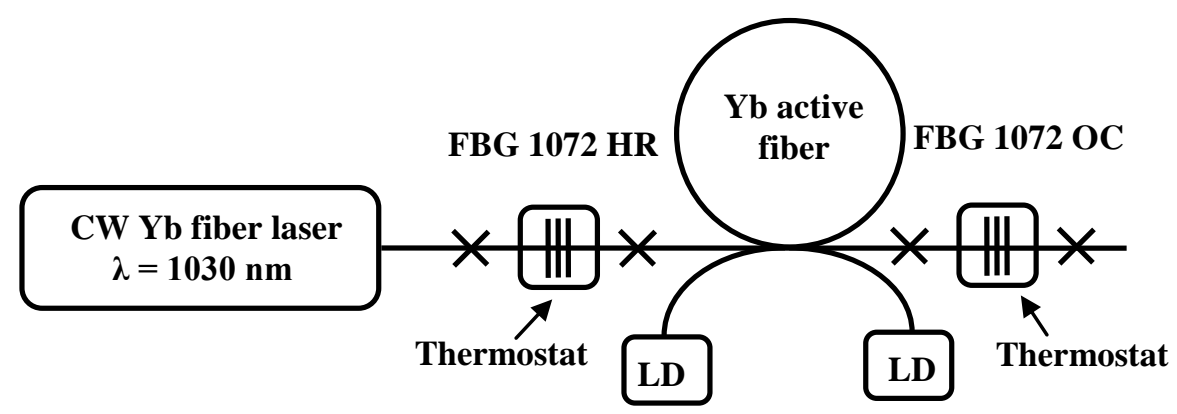

Рис. 1. Оптическая схема мощного узкополосного иттербиевого лазера.

Активное $\mathrm{Yb}$ волокно, разваренное с двух сторон волоконными брэгговскими решетками с узким спектром отражения, накачивается двумя различнми источниками излучения: стандартными полупроводниковыми диодами с длиной волны излучения 975 нм и непрерывным одномодовым поляризованным $\mathrm{Yb}$ лазером с длиной волны 1030 нм (максимальная выходная 
мощность - 66 Вт со спектральной шириной линии 1 нм). Накачка лазером на 1030 нм производилась в световедущую жилу активного волокна.

Было показано, что порог модовой нестабильности при одновременной накачке и волоконным лазером, и диодами зависит от мощности накачки на 1030 нм. В отсутствии накачки на 1030 нм порог МН находится на уровне 2 Вт. С добавлением излучения на 1030 нм удалось получить 100 Вт излучения с длиной волны 1072 нм и спектральной шириной линии менее 0.15 нм (FWHM). Зависимость порога модовой нестабильности от мощности накачки на 1030 нм и спектральной ширины линии от мощности излучения на 1072 нм представлены на рисунке 2.
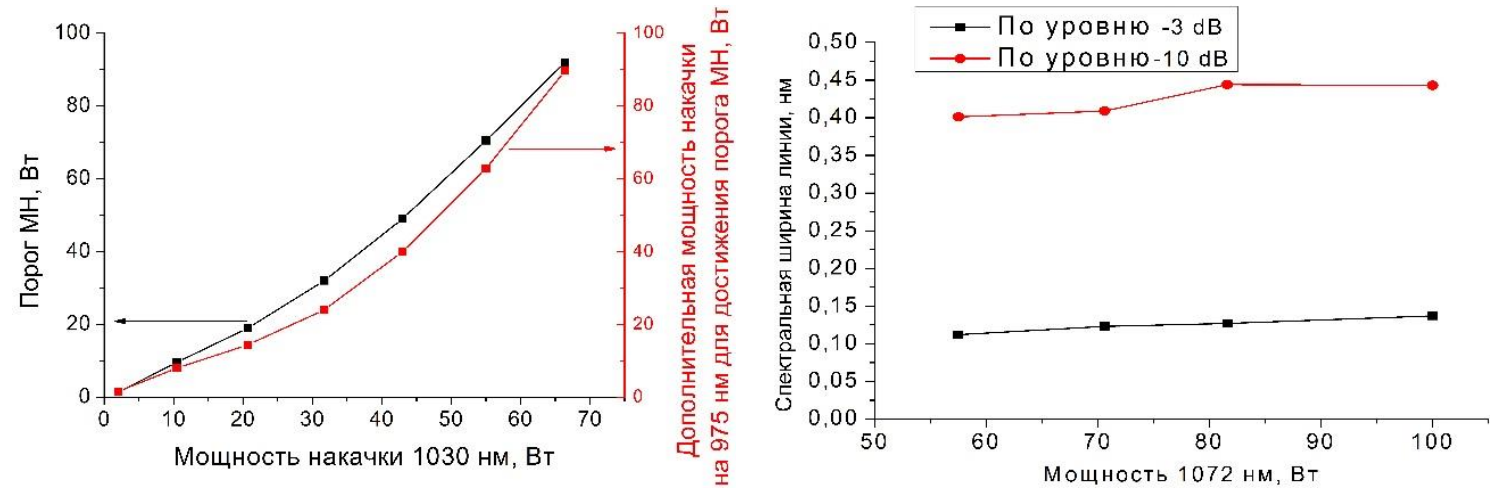

Рис. 2. Зависимость порога МН от мощности накачки (слева) и спектральной ширины линии от мощности лазера 1072 нм (справа).

Таким образом, было продемонстрировано, что дополнительная одномодовая накачка на длине волны 1030 нм позволяет в несколько раз повысить порог МН в лазере при генерации узкополосного излучения в маломодовом активном $\mathrm{Yb}$ волокне.

\section{Литература}

[1] V. Gapontsev, E. Shcherbakov, V. Fomin, A. Abramov, A. Doronkin, Conference Paper, Conference: 17th International Conference «Laser Optics 2016», Saint Petersburg, Russia.

[2] M. Kuznetsov, O. Vershinin, V. Tyrtyshnyy, O. Antipov, Opt. Express 22, 29714-29725 (2014).

[3] B. Yang, H. Zhang at al. J.Opt. 18, 105803 1-8 (2016). 